\title{
Commercial Television in Indonesia
}

The Sindhi Element

\author{
Maria Myutel \\ The Australian National University, Canberra \\ maria.myutel@gmail.com
}

\begin{abstract}
This article sheds light on previously unknown aspects of Indonesian private television by focusing on the role of the ethno-religious minority of Indonesian Sindhi in the establishment and development of commercial soap opera production. Part of the global trading community of Sindhayat, the local Sindhis have mobilized their translocal and transnational networks to take a dominant position in the emerging sector of national media. Grounded in long-term ethnographic fieldwork among media practitioners and Indonesian Sindhi community members, the article examines how Sindhis' sense of community and shared desires and sentiments have resulted in a lack of variety of television formats and the introduction of Islam-themed soap operas to primetime television.
\end{abstract}

\section{Keywords}

Indonesia - national television - Sindhis - sinetron production - Islam - Southeast Asia

\section{Introduction}

National television is as complex as the nation it represents, and Indonesia is no exception. Various culturally and historically differentiated forces have shaped national television in peculiar ways. The complexity of the television industry, especially since its liberalization in the late 1980s and early 1990s, has been reflected in academic scholarship. While political-economy analy- 
sists emphasized the role of the state and capital, ${ }^{1}$ cultural and media studies scholars pointed to the importance of discursive forces, such as nationalism, developmentalism (Kitley 2000; Sen and Hill 200o; Sen 1994), and religion (Barkin 2014; Heryanto 2014; Rakhmani 2014).

This article adds another dimension to the complex world of Indonesian national television by bringing to the fore the Sindhi element: the impact of a tiny, ethno-religious minority of Indonesian Sindhis on the national media production. I argue that Indonesian Sindhis, known in Indonesia as orang India, or Indian people, have played a significant role in shaping the television industry since the early 199os. More specifically, the establishment of a very strong sector of commercial soap opera production, a lack of variety in television programmes, and the introduction of Islam-themed programmes to prime-time television are the major outcomes of the Sindhi presence in the national media. Moreover, I argue that the impact of Indonesian Sindhi businessmen on the Indonesian television industry can only be understood in the context of translocal and transnational networks, which link Sindhis residing in Indonesia with the Sindhayat, a community with a rich history in global trade.

Previous research has largely ignored the role of Sindhis in the Indonesian television industry. Such disregard is due to the fact that scholars of Indonesian media have little knowledge and understanding of the Sindhi community. The only Indonesian Sindhi producer who has attracted a fair amount of scholarly attention is Raam Punjabi. Known as raja sinetron (king of soap opera) to the local media, this extravagant and charismatic figure is indeed difficult to ignore. Understanding Raam's cultural background, his business decisions, and his motivations has not proven to be easy though. Identifying Raam simply as a foreigner from India, cultural-studies scholars have explained Raam's dominant presence in the television business as being due to his large financial investments, reliance on Bollywood and the telenovela-inspired formula (Barkin 2004; Rakhmani 2014), dubious dealings with Bombay soap opera producers (Kitley 2004:147), and sheer talent (Barkin 2004; Kitley 2004; Rakhmani 2014). Overall, scholars have painted an intriguing but also highly unrealistic picture of a sinetron superhero who is single-handedly defining the future of Indonesian commercial entertainment. Moreover, based on the existing literature it is difficult to grasp why other producers in Indonesia were not as talented and had limited access to financial capital and globally circulating formulas of soap opera. In this article, I aim to show that Raam Punjabi is hardly the

1 Hollander, d'Haenens and Bardoel 2009; Ida 2011; Lim 2012; Sudibyo and Patria 2013. 
only producer of Indian descent who can be credited with the establishment of commercial sinetron production, which has become a strong sector in the local economy. The 'Punjabi effect' (Rakhmani 2014:437) has had as much to do with the Sindhi community as it has with Raam's entrepreneurial skills and talents.

To examine how the organized community has shaped the national media industry of Indonesia, I first provide a short introduction to the Sindhis. I then look at the very early days of commercial television, arguing that the global financial and human capital circulated within the Sindhi network played a crucial role in establishing commercial television production as a viable sector of the Indonesian media industry. After that, I move to a discussion of Sindhi business ethics and the importance of owning a business for those who wish to identify themselves with the global trading community. Drawing on an ethnographic study of the television production world and the Sindhi community life in Jakarta, I take a close look at the ways in which the desires and sentiments of Sindhi entrepreneurs have impacted the television industry power play, resulting in a small variety of television products as well as the introduction of Islam-themed sinetron to television prime time. ${ }^{2}$ In the last section, I zoom in further and focus on the case of MD Entertainment, a production house that exemplifies both the past and the future of the Sindhi community, where innovative business practices remain embedded in the traditional networks of business and family.

\section{The Translocal World of Sindhis}

Indonesian Sindhis are part of the global community of Hindu Sindhis, one of the wealthiest and well-connected trading communities in the world. ${ }^{3}$ Originally from Sindh, the former territory of British India and currently part of the Islamic Republic of Pakistan, Hindu Sindhis are now residing all over the world, from Australia to the Philippines, Malta to Latin America. Although merchants

2 The ethnographic data were collected during a six-month fieldwork period in Jakarta in 2013. The author mainly relied on methods developed in media anthropology: in-depth interviews, group discussions, participation in the production meetings, and ethnographic field observation of people, spaces (offices and film sets), and events (press conferences, community celebrations, and award ceremonies).

3 To date there have been only two major studies of the global Sindhi community: an excellent historical account by Markovits (2000) and an in-depth anthropological study of the postPartition community of Hindu Sindhis by Falzon (2004). 
from the Sindh region have been actively involved in transcontinental trading since the mid eighteenth century, the strong sense of Sindhayat ('Sindhiness') is a product of the Partition of 1947: the decision of the colonial elites to split the territory of British India along religious lines caused unprecedented violence, forcing Hindu Sindhis to flee Sindh en masse. Dispersed around the globe, the immigrants from Sindh began to consider themselves as members of 'the same ethnic group or caste sharing a number of common characteristics' (Falzon 2004:38).

Hindu Sindhis claim an Indian identity, maintain an exclusionist, endogamous way of life, and practise a form of Hinduism that is heavily influenced by Buddhism, Sikhism, and Sufism (Markovits 20oo). Endogamy as well as religious and social activities are, however, subordinated to one major constitutive practice-doing business. A Sindhi is brought up with the idea that business defines life and to be a real Sindhi one needs to be in business. As wealth and business acumen define a person's worth (Falzon 2004:189), business is not just about earning one's living. Making money is as much a social, cultural, religious and even an aesthetic practice as it is an economic one. In short, the Sindhi community is 'synonymous with business' (Falzon 2004:189).

Although there are no definite rules and norms that constitute 'Sindhi business' - Sindhis adapt to the laws and regulations of a particular locality by developing practices in response to local contexts-the global connectivity of their local businesses through kinship and ethnic networks is, in fact, typical of Sindhis. While each individual acts as a private entrepreneur, making selfseeking economic choices, the fact that he (or she) is part of a wider group of people, a cosmopolitan community of Sindhis, has a significant impact on his (or her) individual business practices (Falzon 2004:188). In other words, translocality, mobility, and cosmopolitanism are at the core of Sindhiness.

Numbered at around 8,000-10,000, with the majority residing in Jakarta, Indonesian Sindhis have a very pronounced identity (Thapan 2002; Myutel 2016) and a strong sense of community. Since their permanent settlement in Indonesia in the late 1940s and early 1950s, Sindhis have been maintaining their unity and reproducing community boundaries through translocal and transnational practices, such as endogamy, religious rituals, and social gatherings, as well as social institutions. In 1949, Sindhi elders established the Bombay Merchant Association (BMA), defining its membership very bluntly: 'BMA is exclusively for people of Sindhi descent, not anyone else.' ${ }^{4}$ Seeing children's

4 'Bombai Merchant Association belum mati', Tempo Magazine, http://www.library.ohiou.edu/ indopubs/1996/05/04/oo19.html (last accessed 7-4-2016). 
education as one of the BMA's major goals, the association was quick to establish the Gandhi Memorial School, the key community institution for more than 30 years. ${ }^{5}$

Over the course of decades Indonesian Sindhis have stayed true to their identity of global traders: business remains the main occupation of the community members. While around $90 \%$ of Indonesian Sindhis built their fortune in textile trading and manufacturing, several families carved a niche for themselves in Indonesia's media industries, first in cinema (since the 1950s) and later in national television (since the 199os). The entrance into the media production business makes Indonesian Sindhis the only Sindhi community in Asia, with the exception of India, with a substantial presence in, and influence on, this sector of the economy.

This introduction surely paints a very simplified and generalized picture of the community, which has a complex, centuries-long history of transcontinental trading activities. Moreover, being highly attuned to the economic, social, and political changes in Indonesia, India, and elsewhere in the world, the community has never been static. On the contrary, it is constantly evolving, being contested from outside as well as from within, with new generations challenging the norms and testing new grounds. ${ }^{6}$ At the same time, the community's self-identification and strong sense of belonging, as well as sentiments and desires shared by the organized community members, allow me to talk about Sindhiness, or a network of kinship and ethnocultural global connections, as a significant element of national television in Indonesia. ${ }^{7}$

5 For more on the role of this school in the Indonesian Sindhi community, see Myutel (forthcoming).

6 For a detailed account of the global Sindhi community, see Falzon 2004; for a snapshot of the Indonesian Sindhi community, see Thapan 2002 and Myutel 2016 (chapters 1 and 2).

7 Drawing on the work of Yanagisako (2002), I use 'desire' and 'sentiment' not only as ordinary words, but also as terms that have the ability to bring to the fore the cultural aspect, or constituent, of any economic activity. As elegantly argued by Yanagisako, labour and capital are never abstract but 'accumulated, invested, dispersed, and reproduced through historically specific cultural processes' (Yanagisako 2002:5). Using the terms 'desire' and 'sentiment' instead of 'value', 'ideals', and 'goals', helps represent the culturally differentiated complexities of capitalism. 


\section{The Early Days of the Commercial sinetron Industry and Global} Sindhi Networks

Although the Indonesian Sindhi community had nothing to do with the liberalization of Indonesian television in the late 1980 - - an act of political despair that aimed to regain the audience, which was rapidly slipping away from state control due to technological advances such as video, spillover transmission, and transnational satellite (Sen 1994; Kitley 2000) —Sindhi businessmen played a major role in establishing a separate, economically significant, media industry sector: the production of commercial soap operas, or sinetron. The creation of this niche became possible due to the Sindhi community's access to a global pool of financial and human resources. The access to alternative (overseas) sources of capital turned into a serious advantage when traditional institutions (mostly state-owned) that had previously provided media industries with finances and labour became weak and inefficient. The ability of the Sindhis to mobilize ethnic networks allowed them not only to pioneer local soap opera production, but to shape it for more than two decades.

In fact, Sindhi businessmen were no strangers to the media industry when commercial television was first introduced in Indonesia in the late $1980 \mathrm{os}$. Sindhis had been involved in the local film business since the late 1940s, first as importers, distributors, and exhibitors of Indian and American films, and then as producers of local titles. In the 1970s and 1980s the titles released by the Sindhis constituted a significant part (up to a quarter) of the annual production and were highly popular among Indonesian and international audiences. ${ }^{8}$ Overall, Sindhi businessmen were very familiar with local commercial production and international distribution networks.

The liberalization of television presented new business opportunities in the media because the rapidly growing commercial television industry was in constant need of content. ${ }^{9}$ The imported products (in most cases also supplied by Sindhi businessmen ${ }^{10}$ ), which flooded the commercial stations in the early

8 Sindhi producers sponsored such highly popular films as Romi dan Juli (Romeo and Juliette, 1974, Rapi Films); Jaka Sembung (The warrior, 1981, Rapi Films); Catatan si Boy (Boy's diary, 1987, Bola Dunia); Makin lama makin asyik (The longer, the cooler, 1987, Soraya Intercine); the DKI warkop series (1979-early 199os, Parkit Film/Bola Dunia); and Petualangan cinta Nyi Blorong (The love adventures of Nyi Blorong, 1986, Soraya Intercine).

9 For a historical analysis of Indonesian television, see Alfian and Chu 1981, Armando 2011, Kitley 200o, and Sen 1994.

10 Sindhi businessmen mobilized their global connections with leading media distributors, mostly in Latin America and India, to provide commercial television stations, TPI (Televisi Pendidikan Indonesia) in particular, with a steady supply of cheap programmes. 
years, attracted a lot of criticism from various parties for being incompatible with, and harmful to, the Indonesian values (Kitley 2000). In response to criticism, the state pressured commercial stations to allocate no less than $70 \%$ of broadcasting time to local programmes. While still retaining its ideological control over content through Lembaga Sensor Film (the Censorship Body), the state was unable and unwilling to provide rapidly growing commercial television stations with the financial support and trained staff required for the production of local content. The television management also had bigger issues to tackle (such as infrastructure and sponsorship) and outsourced content production to individual entrepreneurs. Within a couple of years, hundreds of production houses (hereafter $\mathrm{PH} \mathrm{s}$ ) were trying to establish themselves in a rapidly growing and highly promising industry.

For independent producers, the production of $\mathrm{TV}$ series/serials for commercial television could guarantee a stable income for years. Since the late 197os, both locally produced series (TV-plays [sandiwara], since 1985 called sinetron) and foreign serials have been favourites with the Indonesian audience (Alfian and Chu 1981; Kitley 2000). At the same time, of all television programmes, the production of series/serials required the most financial and human capital. To secure a foothold in the market, a producer needed to invest at least a quarter of a million dollars. ${ }^{11}$ Moreover, while quiz programmes, for example, could be recorded by two or three people, sinetron production required the coordination of a large number of creative and technical personnel.

For the majority of aspiring producers, local banks and private savings were the only possible sources of financing available within the national borders. Based on my interviews with a large number of media practitioners, local banks, state and private alike, refused to issue loans for commercial production-a new, and thus financially risky undertaking. Even well-respected personalities in the film industry failed to raise money with local monetary institutions. For example, Rano Karno, a very famous actor-turned-producer, was unable to obtain a loan to finance the first episodes of Si Doel anak sekolahan (Educated Doel). To raise funds for the production, Rano Karno had to sell his belongings and mortgage his house (Loven 2008:77).

11 Calculations are based on the following: the minimum cost of one episode in the early 199 os was US $\$ 10$,ooo. In a best-case scenario, commercial television stations would not pay PH s until six months after the first episode was aired (due to delayed transactions with advertisers, the main source of revenue for commercial television stations). As in the 199os each sinetron title was aired once a week, PH s needed to self-finance at least 25 episodes. 
Meanwhile, Sindhis - through their community networks-could secure funding both locally and overseas. ${ }^{12}$ It should be mentioned that for Sindhis, monetary transactions have an important social aspect. Providing a loan and paying it back are ways in which to demonstrate one's wealth, and thus, social prestige within the community, the main source of social acumen for Sindhis. In Indonesia, Sindhis worked with Bank Swadesi, Bank Rama, and Bank Subendra, which were all directly linked to the local Sindhi community. Bank Swadesi was run by the Chugani family; the Harjani family owned shares of Bank Rama; and the owner of Bank Subendra, Sudwikatmono, was in partnership with Harris Lasmana (Haresh Ladharam) and the Fulwani family in the Cinema 21 business. Importantly, the fact that Sindhis usually had other businesses aside from soap opera production, was also to the Sindhis' advantage: banks took less risk in issuing loans to producers who could potentially recover losses in production from side businesses. Moreover, Indonesian Sindhis drew on the capital circulated within the global Sindhi community. Money transfers from overseas partners usually took the form of personal loans, in cash, which resulted in the fast and tax-free accumulation of capital. ${ }^{13}$

Sindhis also mobilized their global community networks to cover the 'creativity gap' (Kitley 2004) in the local market. To tackle the problem of an acute shortage of directors, editors, and scriptwriters, Sindhis reverted to recruiting overseas labour, a practice which they had successfully tested in the film industry in the 1980s. If, for the production of films, Sindhi producers mostly relied on creative labour from the USA, for sinetron production they mobilized their connections with India. Although this preference for using Indian professionals could be explained by the low cost of their labour, cultural considerations also played an important role in the hiring process:

there are no other foreigners [in sinetron production] because it's easier for producers to communicate with Indians. They [Indian professionals] are used to the mess, less expensive, less methodological. So common factor plays its role. ${ }^{14}$

\footnotetext{
12 During my fieldwork, I often came across rumours about the production business in Indonesia (as well as in India) serving as a money laundering mechanism for the global Sindhi community. As the media production business comprises a lot of unregistered financial transactions and operates with large sums of cash, these rumours may have some foundation. I, however, have no evidence to support these rumours.

13 Personal communication with Vijay, an Indonesian Sindhi, 7-2-2013. (All interviewee names are pseudonyms.)

Personal communication with Prashant, Indian national and producer, 7-3-2013.
} 
Professionals from India were a perfect match for the Sindhi producersthey were experienced but affordable, spoke English and Hindi, the 'power languages' of production, but could also learn Indonesian quickly. ${ }^{15}$ They worked hard and were not bothered about rules and regulations (in contrast to professionals from the 'West'). ${ }^{16}$ Although Indian expatriates were not Sindhis, their recruitment was facilitated by the Sindhi connections in Bollywood. It should be mentioned that hiring professionals from overseas required knowledge of the Indonesian labour and migration laws. As Indonesian nationals who had extensive experience in local media production, Sindhis were familiar with the existing restrictions and regulations and the ways to get around them when necessary.

Overseas creative staff had two major responsibilities: to work in their immediate roles as directors, editors, and scriptwriters, and to train locals. In this way, Sindhi-owned PH s became the main training ground for commercial media practitioners. Most sinetron directors, editors, scriptwriters, make-up artists, and production designers who by the 2ooos were well respected in the industry 'graduated' from P T MultiVision (hereafter MultiVision), the largest production house of commercial sinetron, owned by Punjabi brothers Raam and Dhamoo.

The entrepreneurial approach also allowed Sindhi producers (with the Punjabi brothers pioneering this practice) to resolve issues with acute shortages of professional actors. In this case they relied not only on global networks, but also on local kinship connections. This casting strategy deserves attention, because it illustrates the point that Sindhis have 'perfected the practice of moneymaking to a fine art' (Falzon 2004:189). After establishing MultiVision in 199o, Raam and Dhamoo started offering the leading roles in their sinetron to the models who featured in the advertisements produced by Sentra Mega Kreasi, a company founded by their older brother, Gobind Punjabi. ${ }^{17}$ After securing the consent from the models, Raam and Dhamoo would approach international companies, the clients of Gobind, offering them to sponsor the sinetron that featured the 'face' of their company. As a result, MultiVision would offer TV stations a full package - a sinetron with sponsors attached. The MultiVision package was particularly appealing to commercial stations, because other local PH s would usually only come up with a pilot episode, or just a general idea for a potential programme, asking TV stations not only to finance the production

15 For an analysis of the language hierarchy in Indonesian PH s, see Myutel 2017.

16 For example, Sindhis would bring in foreign labour on a tourist visa, and workers from India would usually have no objection to such an arrangement.

17 Gobind Punjabi founded Pт Sentra Mega Kreasi in the same year that his younger brothers, Dhamoo and Raam, established their sinetron production business, PT MultiVision. 
but also to look for sponsors to fill the commercial breaks (Barkin 2004). The approach taken by MultiVision, facilitated by family connections, was a winwin situation for all parties involved. For TV channels, collaboration with MultiVision meant stable, fuss-free revenue. Meanwhile, multinational companies benefited from the partnership with MultiVision because the models representing their products appeared on screen for 30 minutes, the usual length of one sinetron episode in the 1990s, and not for 20-30 seconds. Most importantly, the leading roles of MultiVision sinetron were given to models who had been carefully selected by the well-trained marketing teams of multinational companies, making the Punjabi brothers confident that the audience would find their cast highly appealing.

The local Sindhi networks turned out to be particularly useful when the sinetron industry became an exercise in 'mass production', with television stations demanding new titles every month. As in other businesses, for managerial positions (executives, line producers, heads of departments) Sindhis relied on the local community. The practice of hiring fellow Sindhis is again a matter of social prestige. As Markovits puts it, 'what better way to display one's wealth and enhance one's prestige in such a mercantile society than to offer jobs to scions of poorer families in the community' (Markovits 2000:235). In the case of commercial media production, hiring Sindhis turned out to offer a considerable advantage: Sindhis were professional managers, capable of understanding the market, preparing and controlling production budgets, and serving the needs of the clients, that is, local audiences. In comparison, in non-Sindhi PH s the positions of executive and line producers were mostly held by either a director or a scriptwriter, who-due to their training-had little understanding of production as a business, not an artistic practice (in Indonesia, no film or television school offered production management courses). ${ }^{18}$ Meanwhile, in Sindhi-owned studios, these positions were taken by experienced traders, who saw themselves in an entertainment business serving the tastes of the audience. In sum, both the local and global connections of Indonesian Sindhis have played a significant role in establishing content production as an important sector of the national television industry in Indonesia.

18 For a discussion of the organizational structure of a production house owned by a nonSindhi-Indonesian actor-turned-producer Rano Karno—see Loven 2008. 

Brotherhood and the Sentiment of Independence

If access to global resources was a key factor in the establishment of sinetron production as a profitable sector of the commercial television industry, from the late 199os to the early 2010 Sindhis' desires and sentiments, shaped by decades of transnational trading activities, had a significant impact on the further development of the industry and its end product, the sinetron itself. First, 'corporacy' (Falzon 2004) among Sindhis, and the desire to protect 'their' business niche from outsiders, meaning non-Sindhis, had significantly limited the number of players in the market. This lack of competition resulted in uniformity of the end product. At the same time, the desire of Sindhis to be self-employed, 'be your own boss', kept sinetron production as a separate sector, which meant a relative independence from the state (state legislation regulated broadcasting, but not production). This relative autonomy allowed Sindhi producers to come up with an innovative product, the sinetron Ramadhan, which evolved into a whole new genre of Indonesian television, that is, sinetron Islam (Islamic soap opera), making Islam-themed programmes a significant part of Indonesian popular culture.

\subsection{Sense of 'Corporacy'}

Sindhis' sense of 'corporacy', a term introduced by Falzon (2004) to grasp the notion of 'collective intentionality' that links 'individual economic choice with social patterns' (Falzon 2004:205), had a major impact on the way the commercial television industry developed in Indonesia over the years. Although corporacy does not define particular business practices, it can be called a kind of Sindhi business ethics. As Falzon (2004:8) put it, 'Sindhi sociality and business may be very variable phenomena, according to the conditions [...] in the various locations of settlement, yet certain processes are at work that make group corporacy a factor to be reckoned with'. In the Indonesian television context, Sindhi corporacy resulted in a highly conservative industry, with new, non-Sindhi players finding it incredibly difficult to establish themselves in the Sindhi-dominated environment.

The corporacy of Sindhis should not be understood as creating unconditional mutual support. In fact, Sindhi businessmen are engaged in highly ambivalent relationships. On the one hand, Sindhis are in constant competition with each other, because they tend to stay in the same business niche. ${ }^{19}$ When they

19 For example, in Hong Kong Sindhis are active in manufacturing garments and electron- 
are ready to start their own business, former employees of Sindhi companies establish themselves in exactly the same niche as their former bosses. Similarly, after partnerships break up, former partners become each other's main competitors. Although competing with former employers or partners is a very common practice, it always causes serious tensions among community members. On the other hand, Sindhis prefer doing business with each other. As a rule, any expansion of the business to another locality, be it within or beyond national borders, starts with contacting the local Sindhis. Most importantly, Sindhis join hands when a non-Sindhi competitor tries to enter 'their' niche: 'cooperation and zero-sum competition are equally common and often articulated in similar ways between Sindhis because they are two sides of the same coin: corporacy' (Falzon 2004:236).

These business habits constitute everyday realities for most Sindhi entrepreneurs in Indonesia. Sindhis are each other's most serious competitors, but at the same time 'their brotherhood is strong', as my respondents often pointed out to me. Despite being in fierce competition with each other, they come together when a new player starts posing a threat to their business acumen: 'They fight each other, but if there is a new production house, they'll fight against it together.'20 The practices used by Sindhis to protect their niche from outsiders allegedly included 'price wars' (selling the end product at prices much lower than the production cost); bribing AC Nielsen, the rating-measuring body (Barkin 2004:chap.2); influencing vote counting for television awards; and intimidating newcomers, especially those who dared to offer new ideas or formats.

In one way or another, the Sindhi entrepreneurs were very effective in protecting the sinetron production sector from non-Sindhi competitors. During the period 1990-2013 there was only one non-Sindhi producer, Leo Sutanto, an Indonesian of Chinese descent, who challenged the Sindhi dominance. All other new PHs that emerged in the period between the mid 199os and the early 2010 and managed to occupy a strong position in the market were actually companies that had branched off from the major Sindhi PH s. StarVision (est. 1995) was founded by Shanker Rs (Shanker Ramchand Shamdasani), the former executive producer of MultiVision who partnered with Chand Parvez, an Indonesian of Pakistani descent (in other words, a descendant of immigrants from Sindh who practised Islam, not Hinduism). PT MD Entertainment

ics; in the Philippines, in retail trade and money lending; and in Indonesia, in textile and luxury-goods trading.

2o Personal communication with Danang, the director of a major television station, 23-42013. 
was established as a result of the split (2003) between the two founding partners of MultiVision, the Punjabi brothers Raam and Dhamoo. PT Screenplay (est. 2010) was founded by two former employees of MultiVision:Wicky Olindo and Sugdev Singh. PT Mega Kreasi (est. 2013), one of the major suppliers of FTVs ( film televisi, or television films, a subgenre of sinetron), branched off from Rapi Films, one of the first sinetron PH s, established by Samtani brothers Gope and Shankar back in $1993 .{ }^{21}$ As one of the top sinetron producers put it bluntly: 'There are so many players-3,00o [...] But the real performers are five, out of which four are owned by Indians and one is owned by a Chinese.'22

After several failed attempts to make it in commercial television, Leo Sutanto's sinetron business finally took off in 2003, and this was no coincidence. In 2003, Dhamoo Punjabi, the founding partner of MultiVision, left the company to establish his own production business, MD Entertainment. Being weary of the decade-long dominance of MultiVision, major television stations used the split to their advantage: SCTV allocated all hours of MultiVision to the newly established MD Entertainment, while RCTI, acquired by Hary Tanoesoedibjo (Hary Tanoe), offered all the MultiVision hours to Leo's new company, SinemArt. ${ }^{23}$ With the reserved television slots, SinemArt and MD Entertainment were 'destined' for success. Without the split, MultiVision, together with other Sindhi-owned companies, would most probably have been able to protect the niche and retain its leading positions, as it had done for more than a decade (1990-2003).

Although the reshuffling in the industry allowed television stations to regain control over their programming schedule (which was previously controlled by the Punjabi brothers), the presence of two new players in the market had no drastic impact on television content. ${ }^{24} \mathrm{~A}$ decade of Sindhi dominance in the market had formed the tastes of the audience. While accepting some superficial, 'cosmetic' changes (instead of copied telenovelas, MD Entertainment and SinemArt offered derivatives of Korean and Taiwanese dramas), the audience showed resistance to drastic changes of format and genre. For example, in 2006 Leo Sutanto invited acclaimed Tempo journalist and novel writer Leila Chudori to write an innovative scenario for the show Dunia tanpa koma (The world

21 It should be mentioned that PT Mega Kreasi is the only PH headed by a Sindhi business woman. For more on the role of Sindhi women in Indonesian television industry see Myutel 2016 (Chapter 6).

22 Personal communication with Mahendra, an Indonesian Sindhi, 7-2-2013.

23 Leo Sutanto and Hary Tanoesoedibjo knew each other through the Cinema 21 business.

24 For more than a decade, TV stations were under the 'dictatorship' of PH s, MultiVision in particular. Raam Punjabi 'controlled advertisers and made sure MultiVision sinetron titles were not aired simultaneously by competing stations' (Rakhmani 2014:439). 
without commas, henceforth DTK), which would address socially meaningful topics. ${ }^{25}$ Despite (or because of) its novelty, topicality, and high production value, the show turned out to be a flop. The dominance of the Sindhi-owned companies also had an impact on the labour force in the market. As discussed, locally available media practitioners were trained by MultiVision and other Sindhi-owned companies (Rapi, Soraya Intercine, and StarVision) and had no skills to make technically and dramatically innovative series.

In sum, the sense of 'corporacy' among Sindhi sinetron producers has considerably limited the competition in the market, resulting in a small variety of sinetron formats and genres. It also contributed to the formation of audience tastes. Of course, poor variety was also a risk-aversion strategy used by the television management (Rakhmani 2014; Barkin 2004), but this strategy alone does not fully explain the stable success of very few sinetron $\mathrm{PH} s$ and the absence of new entrants.

\subsection{The Sentiment of Independence}

Along with a sense of brotherhood, the sentiment of independence, the ultimate desire of Sindhis to own a business, also significantly shaped the development of the television industry and its end product. To be a true Sindhi it is not enough just to be in business - one has to own one. Even if younger Sindhis often choose to launch their careers in international companies rather than in the family business, after several years most go into private entrepreneurship. The increasing interest in professional careers among the younger generations is mostly about creating a new path to the same old goal-self-employment. Such a focus on business ownership has historically resulted in several peculiarities of Sindhi businesses. For example, Sindhi-owned companies rarely outlive two generations and do not grow into conglomerates. Sindhi entrepreneurs favour only short-term investment and prefer expanding businesses to new localities rather than investing in further business development in the same country. To sum up, business ownership and the number of businesses owned continue to gain most prestige within the community. ${ }^{26}$

As mentioned earlier, the development of soap opera production into a rather independent and strong branch of the media industry was not an auto-

25 The story of DTK's first season revolved around journalists investigating a drug syndicate in Jakarta.

26 Those Indonesians of Sindhi descent who have no aspirations to be in business usually cease to be active members of the Sindhi community - they feel that they do not belong and are not welcome. For example, Dani (pseudonym), a Sindhi who chose to be an artist, withdrew from the Sindhi community almost completely. 
matic outcome of television liberalization and commercialization. The production of local television can be carried out by private television stations, which in industry terms is known as 'in-house production', or by freelance producers who mobilize financial and human capital, and production facilities on a project basis. During the initial years of commercial television, the production of local soap operas was indeed something that was practised by a random selection of individual producers. By drawing on an international pool of funding, human capital, and creative ideas, Sindhis were, however, able to turn these random production practices into routine. Sinetron production quickly grew into a fully fledged industry, with an estimated turnover of hundreds of millions of dollars (Rakhmani 2014:441).

From an economic point of view, as soon as sinetron PHs started generating big profits, they should have been taken over by media conglomerates. The acquisition of sinetron production businesses by private television stations seemed particularly logical in the Indonesian case, as during the first decade of commercial television (1990s-2003) sinetron producers-to the great discontent of television managers-largely gained full control of the everyday schedules (Rakhmani 2014). There were, however, no cases of acquisition of major PH s by the television stations. Although sinetron PH s established close, in many ways exclusive, relationships with the stations, they were still independent, mostly family-owned businesses, and not subsidiaries of the major media conglomerates. Drawing on an analysis of Western industries, Hesmondhalgh (2013) explains the continuing presence of small media companies by new media technologies, the rise of a discourse of entrepreneurship in the economy as a whole, easier access to venture capital, and the overall increasing role of marketing (2013:209-10). I argue that in the Indonesian context the persistent presence of relatively small but strong companies can be explained by similar, but culturally specific, sentiments of independence among Sindhi businessmen. As mentioned earlier, their access to alternative human and financial capital through ethnic and kinship networks also played a role.

As PH s were not part of any television stations, and were not owned by them, the policies regulating television content did not apply to the production studios directly. ${ }^{27}$ The existing laws regulated broadcasting, but not production as such, meaning that legally the responsibility for the content lied with the television stations. Thus, the relationships between the PH s and the state were

27 Prior to 2002 the laws governing the television industry were issued by the Departemen Penerangan (Ministry of Information); from 2002 onwards, by the Komisi Penyiaran Indonesia (KPI, Indonesian Broadcasting Commission). 
mediated by television executives. Such arrangement was the legacy of precommercial television, when both production and broadcasting were in the hands of the state and a separate regulation of content production was not required.

This relative independence of the sinetron production industry from television stations and from the state, especially during the first decade (the 199os), had quite an unexpected result. In 1998, MultiVision produced the sinetron Ramadhan, a show that revolutionized local television in several ways. At the level of representation, the sinetron Ramadhan became the first Islamicthemed prime-time show in which an 'Islamic ambience' was expressed through its narrative, with an emphasis on prayer and devotion, as well as its aesthetic aspects (Ida 2009). During the New Order, the state television promoted a secularized representation of the Indonesian nation and religiously themed programmes occupied an insignificant part of the television schedule (Rakhmani 2013). Moreover, none of the officially recognized religions was given priority in TV programming. As Rakhmani (2013:31) pointed out, 'secularisation' and 'symbol wielding' were 'fundamental traits for TVRI under New Order's single state television system $(1965-1989){ }^{\prime 28}$ Even after the introduction of commercial television, the programmes, mostly local adaptations of foreign programmes, were stripped of any religious symbolism. In other words, in the 199os television stations were very cautious about prioritizing one religion over the other.

Meanwhile, private, independent PH s, such as MultiVision, could afford to experiment with the sinetron content, including religion-related themes and symbols. The independent status of sinetron $\mathrm{PH}$ s also provided television management with some freedom of manoeuvre - in case of public outrage, television executives could blame PHs, playing on the ambiguity implied by the laws regulating television content. It turned out that RCTI, the first television station to broadcast sinetron Ramadhan, did not have to accuse MultiVision of breaking the taboo on mainstreaming Islam. The show, Doaku harapanku (My prayers, My hopes, 1998-2000), was 'a tremendous success in the ratings from its first week [...] followed by an onslaught of copy-cat programmes from every major station' (Barkin 2014:13). Equally important is the fact that 'the program's success called into question the wisdom behind the industry's longstanding avoidance of such themes' (Barkin 2014:13). Television producers were left wondering whether it was time to break other unspoken rules that had

28 TVRI (Televisi Republik Indonesia) was the only television station in Indonesia in the period 196os-1980s. For a detailed account of Indonesian television during this period, see Kitley 2000. 
constrained production. In other words, in the 199os television stations, on their own, would not have initiated sinetron Ramadhan as prime-time entertainment, despite the growing Islamization. ${ }^{29}$ The relative autonomy of the sinetron $\mathrm{PH}$ s, however, considerably sped up the process of making Islam a significant part of Indonesian television.

The sinetron Ramadhan also had a significant impact on the production process, as they introduced 'strip programming' (everyday broadcasting and production) to the Indonesian television industry. Unlike other TV shows of the 1990s, produced to air once a week, the sinetron Ramadhan episodes were shown every day throughout the holy month. For the first few years, strip programming was just the broadcasting model used during the holy month of Ramadhan, but with the increased competition among free-to-air television stations, with five new national TV stations coming to the market between 1998 and 2003, strip programming became the dominant model for all sinetron production. Strip programming, which limited the production time for each episode to one day instead of three or four, led to a significant decrease in the quality of sinetron. The introduction of this model became a major milestone in the national television history, with industry workers referring to two major periods - before and after the introduction of strip programming (not before and after the fall of the New Order regime, as readers familiar with Indonesian history might assume).

In sum, the sense of brotherhood and the sentiment of independence shared by Sindhi producers had a major impact on the further development of the Indonesian television industry. The absence of newcomers, due to the Sindhi dominance in the market, limited the variety of programmes. At the same time, being relatively autonomous from the state, Sindhi-owned production companies could experiment with entertainment content, offering Indonesian audiences an unusual but, as it turned out, highly desired television formatsinetron Islam.

\subsection{The Case of $M D$ Entertainment}

The case of MD Entertainment briefly discussed above is worth a closer examination, as it demonstrates particularly well the ever-changing, ever-evolving nature of the Sindhi community practices in response to local political, economic, and social conditions as well as global trends. While Indonesian commercial television evolved under the influence of Sindhi business ethics and

29 On the rapid Islamization of Indonesia see, for example, Heryanto 2014 and Rakhmani 2013. 
practices, Sindhi entrepreneurs who operated in the highly dynamic and volatile environment of post-Suharto Indonesia also experimented with new strategies and concepts.

As mentioned earlier, MD was established after one of MultiVision's founding partners, Dhamoo Punjabi, together with his son, Manoj, at that time an employee of MultiVision, left the company to start their own company. The split between the Punjabi brothers occurred at the peak of MultiVision's success, when the company was producing 60 to $70 \%$ of the total soap opera titles aired on $\mathrm{TV}$ (Loven 2008:49). This split is difficult to explain from the perspective of top business priorities being continuous growth, profit accumulation, and business consolidation. From a Sindhi perspective, however, such a course of events was logical, even natural: for Sindhis the ownership of a company, and not the company size or value, bears most prestige. A year before the split, in 2002, Manoj Punjabi, who took the official leadership role in MD, got married, and his new social status obliged him to think of his own business, to make the important step from being 'in service' to becoming a boss.

While establishing their business, Dhamoo and Manoj followed the canonical Sindhi practices. First, they went into exactly the same field as their former partner/employer: the production of sinetron. Being one of the richest Sindhi families, Dhamoo and Manoj Punjabi had no issue with initial capital, relying on personal savings and kinship support. ${ }^{30}$ For human capital Manoj drew on the organizational practices that were in place in MultiVision and other Sindhiowned PH s: executive positions were filled by local Sindhis, mostly Manoj's classmates from the Gandhi Memorial School, while creative roles were allocated to professionals from India, who, prior to joining MD, had worked in the biggest Indian television PH s, like Ekta Kapoor's Balaji Telefilms. As for the stories, MD also chose to stick to well-tested global formulas, fully relying on adaptations of telenovelas and South Korean and Taiwanese dramas. A sense of corporacy and desire for independence were also at the core of Manoj's philosophy. In the 2010s, MD often figured in rumours about unhealthy business practices, such as knock-down prices, and manipulations with ratings and popularity votes for people's choice awards. Moreover, despite exclusive relationships with several television channels, MD rigorously maintained its independence.

Typical in many ways, MD, however, followed a route unusual in Sindhi business circles. As the business grew, MD started offering new products and

30 Manoj's wife, Shania (born Lakhiani), hails from one of the most respected and wealthiest Sindhi families in the Asian region. 
services: it went into the production of feature films and animation and established its own television channel. Moreover, instead of gaining tight control over the whole business chain from distribution to exhibition, MD mostly focused on developing production facilities, building shooting pavilions and trick rooms, and investing into animation hard- and software. By the late 2010s, MD had grown into a corporation, MD Corp, well-established in the big-screen industry (MD Pictures), music (MD Music), animation (MD Animation), property (MD Graha Persada), and several other businesses. In August 2018, MD Pictures became the first Indonesian film company (and possibly the first Indonesian Sindhi company) to go public and enter the Indonesian stock market. ${ }^{31}$

In comparison, MultiVision continued expanding its business in a 'Sindhi way' - establishing similar businesses in different localities. Since the late 20oos MultiVision has not only been a film distributor, but also a producer of local feature films and television programmes in Malaysia, Vietnam, Thailand, Cambodia, and Laos. MultiVision has also retained control over distribution and exhibition, investing in movie theatres across the archipelago and neighbouring countries in the Asia-Pacific region.

Moreover, Manoj has explicitly adopted the rhetoric of nationalism as part of his business strategy, promoting his company first and foremost as a national business and only then as a global one. In one of its first promotional videos, $\mathrm{MD}$ is called 'Indonesia's first integrated global media and entertainment company' ${ }^{\prime 2}$ The video also features major figures from the Indonesian political, religious, and social elites praising Manoj for his contribution to the national media industry. Habibie, a former president of Indonesia, calls Manoj 'Indonesia's newest icon', who 'is representing all of us, who has the honour and also the responsibility to carry the flag. Overall, the video is saturated with nationalist paraphernalia. While utilizing nationalist rhetoric might seem an obvious strategy for media companies that wish to succeed in the current (2010s) Indonesian environment, it is actually not the case. Manoj's peer, Sunil Samtani, the owner of Rapi Films - another prominent, although smaller, player in the sinetron (and film) industry—does not find it necessary to appeal to nationalist sentiments to succeed in the national television industry. In his interview with The Hindu, Sunil stated that 'my [Indonesian] passport is just a formality. We are Indians. Our relationship with Indonesians is business-

31 https://www.tabloidbintang.com/film-tv-musik/kabar/read/108386/md-pictures -menjadi-perusahaan-film-pertama-yang-go-public (last accessed 21-4-2019).

32 The video can be accessed here: https://www.youtube.com/watch?v=aJsrxH1HLtc (last accessed 21-4-2019). 
oriented'.33 Overall, the MD case, especially when compared with other Sindhiowned PHs, provides a good example of how Sindhi entrepreneurs, pursuing individual goals and making personal, often unique choices, continue to rely on the well-established practices and networks of the Sindhayat.

This article has shed light on previously unknown aspects of Indonesian commercial television: the influential role of Sindhi producers in the establishment and development of a highly profitable sector of the Indonesian media-the production of commercial soap opera. I argued that the contribution of Sindhis to national television can only be understood in the broader context of global networks and community business practices. Without prior knowledge of the Sindhi community, the success of Indians in the industry looks like a long-term stroke of luck that hit a couple of individuals. Meanwhile, the understanding of the Sindhi community past and present, its links to the world through two 'most fundamental networks: business and family' (Falzon 2002:64), allows us to see that the strong presence of Indonesian Sindhis in media production is the result of the everyday work of the community on local, regional, and global levels. Through a myriad of transnational connections, Indonesian national television has been linked not only with India, but also with other financial and creative centres of the world, such as Hong Kong, Singapore, the USA, and Latin America.

The involvement of the Sindhi community has shaped national television in some peculiar ways. Tight control of the niche that Indonesian Sindhis carved out for themselves in the newly established industry of commercial television resulted in a poor variety of programmes for many years. With almost no newcomers entering the sector, the dominant players had little incentive to introduce new formats and engage with unconventional topics. At the same time, quite unexpectedly, the introduction of Islam-themed programmes as a prime-time entertainment genre can also be linked to the Sindhi presence in the television industry. The relative autonomy from the state provided privately owned PH s with an opportunity to align more with the rapidly changing tastes of the audience, rather than with the state regulations and unwritten norms and taboos.

33 Pallavi Aiyar, 'Sindhi kings of Indonesian entertainment', The Hindu, last modified 24-8-2013, http://www.thehindu.com/opinion/op-ed/sindhi-kings-of-indonesian -entertainment/article5052949.ece?css=print (last accessed 2-9-2013). 
More broadly, this article has sought to once again draw attention to the complexity of contemporary Indonesia, where ethno-religious minorities and the nation-state are interlinked in the most unexpected ways, and in ways which disregard both real and imagined political, geographical, and cultural boundaries. While Sindhiness has been interwoven with the everyday transactions and processes of national television in Indonesia from its early years onwards, the cosmopolitan Sindhis have recently started exploring the concept of nationalism. Overall, the mediated relationships between the Indonesian nation-state and the local Sindhis have enriched the modern history of the country and the global community of Sindhis.

\section{Acknowledgements}

The author would like to thank two anonymous reviewers for their thoughtful comments and suggestions.

\section{References}

Alfian, and Godwin C. Chu (eds). 1981. Satellite television in Indonesia. Honolulu: LEKNAS/LIPI, East West Center.

Armando, Ade (2011). Televisi Jakarta Di Atas Indonesia. Yogyakarta: Penerbit Bentang Anggota Ikapi.

Barkin, Gareth (2004). Producing Indonesia: The derivation and domestication of commercial television. [PhD diss., Washington University.]

Barkin, Gareth (2014). 'Commercial Islam in Indonesia: How television producers mediate religiosity among national audiences', International Journal of Asian Studies 111:1-24.

Falzon, Mark-Anthony (2004). Cosmopolitan connections: The Sindhi Diaspora, 186020oo. Leiden and Boston: Brill.

Heryanto, Ariel (2014). Identity and pleasure: The politics of Indonesian screen culture. Singapore: NUS Press.

Hesmondhalgh, David (2013). The cultural industries. Los Angeles and London: Sage.

Hollander, Ed, Leen d'Haenens, and Jo Bardoel (20o9). 'Television performance in Indonesia: Steering between civil society, state and market', Asian Journal of Communication 19-1:39-58.

Ida, Rachmah (2009). Imaging Muslim women in Indonesian Ramadan soap operas. Chiang Mai: Silkworm Books.

Ida, Rachmah (2011). 'Reorganisation of media power in post-authoritarian Indonesia: 
Ownership, power and influence of local media enterpreneurs', in: Krishna Sen and David T. Hill (eds), Politics and the media in twenty-first century Indonesia: Decade of democracy, pp. 13-25. London and New York: Routledge.

Kitley, Philip (2000). Television, nation and culture in Indonesia. Athens and Chicago: Ohio University Center for International Studies.

Kitley, Philip (2004). 'Closing the creativity cap-renting intellectual capital in the came of local content: Indonesia in the global television format business', in: Albert Moran (ed.), Television across Asia: Television industries, programme formats and globalization, pp. 138-156. London: Routledge Curzon.

Lim, Merlyna (2012). The league of thirteen: Media concentration in Indonesia. Tempe, AZ: Participatory Media Lab at Arizona State University and Ford Foundation.

Loven, Klarijn (2008). Watching Si Doel: Television, language, and cultural identity in contemporary Indonesia. Leiden: KITLV Press.

Markovits, Claude (2000). The global world of Indian merchants, 1750-1947: Traders of Sind from Bukhara to Panama. Cambridge: Cambridge University Press.

Myutel, Maria (2016). Indians and national television in Indonesia:Behind the seen. [PhD diss., The Australian National University.]

Myutel, Maria (2017). 'Ethnicity and social relations in Indonesian television production houses', Journal of Southeast Asian Studies 48-2:219-36.

Myutel, Maria (forthcoming). 'Minority and advantage: The story of Sindhis in Indonesia', in: Greg Fealy and Ronit Ricci (eds), Contentious belonging: The place of minorities in Indonesia. Singapore: IsEAs Publishing.

Rakhmani, Inaya (2013). Rethinking national identity in an age of commercial Islam: The television industry, religious soap operas, and Indonesian youth. [PhD diss., Murdoch University.]

Rakhmani, Inaya (2014). 'Mainstream Islam: Television industry practice and trends in Indonesian sinetron', Asian Journal of Social Sciences 42:435-66.

Sen, Krishna (1994). 'Changing horizons of television in Indonesia', Southeast Asian Journal of Social Science 22:116-24.

Sen, Krishna, and David T. Hill (eds) (200o). Media, culture and politics in Indonesia. Melbourne: Oxford University Press.

Sudibyo, Agus, and Nezar Patria (2013). 'The television industry in post-authoritarian Indonesia', Journal of Contemporary Asia 43-2:257-75.

Thapan, Anita Raina (2002). Sindhi diaspora in Manila, Hong Kong, andJakarta. Quezon City: Ateneo de Manila University Press.

Yanagisako, Sylvia Junko (2002). Producing culture and capital: Family firms in Italy. Princeton and Oxford: Princeton University Press. 